Pak. j. sci. ind. res. Ser. B: biol. sci. 2018 61B(2) 72-77

\title{
Impact of Different Shapes of Pitchers on Water Saving and Water Use Efficiency of Ridge-gourd in Semi Arid Region of Pakistan
}

\author{
Ashifa Soomroa ${ }^{a}$ Kamran Baksh Soomro*b, Azhar Ali Lagharia and Samina Siddiquic \\ ${ }^{a}$ Department of Land and Water Management, Sindh Agriculture University Tandojam, Sindh, Pakistan \\ ${ }^{\mathrm{b} C}$ Civil Engineering Discipline, School of Engineering, Monash University, Malaysia \\ ${ }^{c}$ National Centre for Excellence in Geology, University of Peshawar, KPK, Pakistan
}

(received December 3, 2016; revised December 5, 2017; accepted February 13, 2018)

\begin{abstract}
Pitcher irrigation is an ancient irrigation system, used for cultivation of small areas where water is saline and not fit for surface irrigation. This research aims to investigate the effect on water use efficiency and water saving of ridge gourd by utilization of different shapes of pitchers. Ridge-gourd was planted under four different pitcher shapes including $\mathrm{T}_{\mathrm{I}}$ (conical), $\mathrm{T}_{2}$ (spherical), $\mathrm{T}_{3}$ (round) and $\mathrm{T}_{4}$ (cylindrical) shapes at the experimental field of Sindh Agriculture University Tandojam, Pakistan. Overall sixteen clay pitchers having 1.7, 1.3, 1.3 and $1.08 \mathrm{~m}^{3}$ volume of water under $\mathrm{T}_{1}, \mathrm{~T}_{2}, \mathrm{~T}_{3}$ and $\mathrm{T}_{4}$ respectively were installed in the soil. The irrigation water having electrical conductivity (EC) $1.3 \mathrm{dS} / \mathrm{m}$ with $\mathrm{pH}$ of 7.8 was used to fill the pitchers. The highest soil EC of $3.32 \mathrm{dS} / \mathrm{m}$ at $0-20 \mathrm{~cm}$ depth of soil was found under $\mathrm{T}_{4}$ followed by $T_{3}, T_{2}$ and $T_{1}$, respectively. Whereas $T_{4}$ showed minimum soil EC as $1.30 \mathrm{dS} / \mathrm{m}$ at the depth of $40-60$ $\mathrm{cm}$. However the $\mathrm{pH}$ effect of $\mathrm{T}_{1}$ was slightly higher as 8.4 at the depth of $40-60 \mathrm{~cm}$ in comparison to $\mathrm{T}_{2}$, $\mathrm{T}_{3}$ and $\mathrm{T}_{4}$, whereas the minimum $\mathrm{pH}$ of 8.0 was found at $20-40 \mathrm{~cm}$ under $\mathrm{T}_{4}$. The maximum vine length of ridge gourd was $211 \mathrm{~cm}$ under $T_{4}$ and the minimum length of vine was $139 \mathrm{~cm}$ under $T_{2}$. The highest water use efficiency $8.6 \mathrm{~kg} / \mathrm{m}^{3}$ was obtained under $\mathrm{T}_{4}$ whereas the highest water saving as $82 \%$ was recorded under $\mathrm{T}_{4}$ followed by $\mathrm{T}_{2}, \mathrm{~T}_{1}$ and $\mathrm{T}_{3}$.
\end{abstract}

Keywords: Pitcher irrigation, Ridge gourd, water use efficiency, water saving, vine length

\section{Introduction}

Water scarcity has been graded as a serious threat globally for arid and semi-arid zones. Fresh water reservoirs are limited, only $3 \%$ of the entire water reservoirs ( $2 \%$ ice water and $1 \%$ fresh water) are utilised for agricultural application, however, a big portion of water i.e., $97 \%$ sea water is highly saline and generally not appropriate for agricultural utilisation. Additionally, more than half of the ground water supply worldwide also turned out to be saline (Bruinsma, 2003). In Pakistan, the indiscriminated discharge of water from domestic and industrial waste into open water, as well as to ground water are amongst the leading threats towards water reserves (Kahlown and Majeed, 2003).

Considering the rise in demand of water for agricultural and industrial need and fast deterioration of irrigation water, a number of attempts have been made to meet the water requirement in agriculture. The per capita availability of water has immensely decreased globally (Ayers and Westcost, 1985). In Pakistan the per capita *Author for correspondence; E-mail: kamran.baksh@monash.edu water availability has drastically declined from 5,600 $\mathrm{m}^{3}$ in year 1947 to around $1,100 \mathrm{~m}^{3}$ in 2011. Based on the current situation of decline in per capita water, it is anticipated that in 2025 the water availability will be declined to around 800 cubic meter that will make Pakistan a water scarce country (Bruinsma, 2003). This situation will be more alarming and become worsen by an increase in population to predicated 220 million by 2025 (Qureshi, 2011). The main source for irrigation in Pakistan is the Indus River system; roughly about $54 \%$ of water is lost due to seepage and evaporation, due to which it is predicted that there might be a significant decline in food production to meet the demand of growing population (Gul and Khan, 2003).

Pakistan is at the initial stage as far as water conservation technologies are concerned. Most of the irrigation practices are only revolving around furrow and flood irrigation, with efficiency ranges between 40 to $50 \%$ (Hillel, 1997). Due to poor application efficiency, not only huge amounts of water are lost but problems of salinity and water logging are also formed (Ishfaq, 2002). Thus, execution of efficient irrigation conservation 
technologies like pitcher and drip irrigation needs to be highlighted and implemented to increase the crop water production. To meet the crop requirements, the demand of water is high particularly in the dry regions of the world including Pakistan. It is judicious to use water efficiently to increase crop production per unit volume of the water application (Agarwal, 2000).

Pitcher irrigation is an ancient irrigation system invented in northern Africa and Iran. In fact, it is also verified through Chinese scripts courting back to more than 2000 years (Sheng, 1974). This system is used for cultivation of small areas where water is saline and not fit for surface irrigation (Bhatt et al., 2013). Pitcher irrigation is graded as water saving, economical and simplest method for irrigation purpose and its effectiveness is also proved in previous research studies both in arid and semi-arid zones in different parts of the world like Iran, India, and few African countries (Vasudevan et al., 2014; Siyal et al., 2013; Tesfaye et al., 2012; Bainbridge, 2001). The application of pitcher irrigation can save approximately 3-60\% of water in comparison to surface and drip irrigation system (Ansari et al., 2015). Pitcher irrigation tends to maintain soil moisture that help the crops to grow irrespective of nature of soil (whether saline or basic) and it is most suitable option for saline water (Mondal et al., 1992; Alimi, 1981). The application of pitchers in irrigation is gaining substantial attention in arid and semi-arid lands due to its simplicity and auto-regulative capabilities (Abu-Zreig and Atoum, 2004). The radius of soil wetting front and seepage rate should be determined prior to installation of pitchers, as it will support in placing distance between pitchers in order to avoid overlap of wet areas to each other (Ghafoor et al., 2016).

This research aims to investigate the effectiveness of diverse shapes of pitcher on water use efficiency and water saving of ridge gourd.

\section{Materials and Methods}

A completely randomised design (CRD) experiment with four different treatments including four replications were performed at the experimental field of Faculty of Agricultural Engineering, Sindh Agriculture University Tandojam during 2015-2016. The site for experiment was situated at Latitude $25^{\circ} 25^{\prime} 28^{\prime \prime} \mathrm{N}$ and Longitude $68^{\circ} 32^{\prime} 26^{\prime \prime} \mathrm{E}$ and about $26 \mathrm{~m}$ above sea level. The experimental plot area was $25 \mathrm{~m}^{2}$ measuring $5 \mathrm{~m} \times 5 \mathrm{~m}$. The map of the experimental sites is given in Fig. 1.
Sixteen pitchers were buried at a distance of $1 \mathrm{~m}$ as shown in Fig. 2. Before the installation of pitchers the samples of soil were taken at 0-20, 20-40, 40-60 cm depths and were analysed for physicochemical properties. The samples were then air dried and passed through $2 \mathrm{~mm}$ sieve and were investigated in the laboratory as advised by Isbell (1996).

The labelling of samples was done after packing in order to bring these samples for soil and water testing laboratory at Tandojam, Pakistan, for investigation of

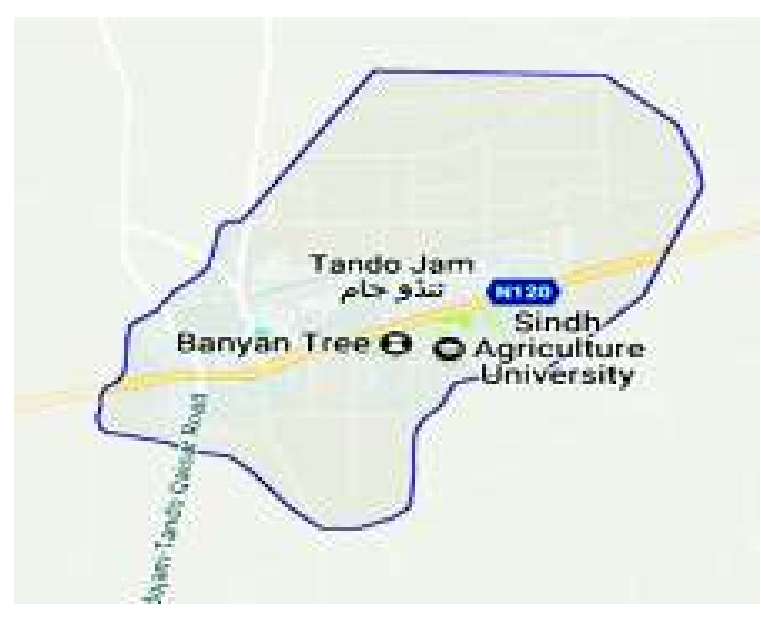

Fig. 1. Map of the location of experimental site.

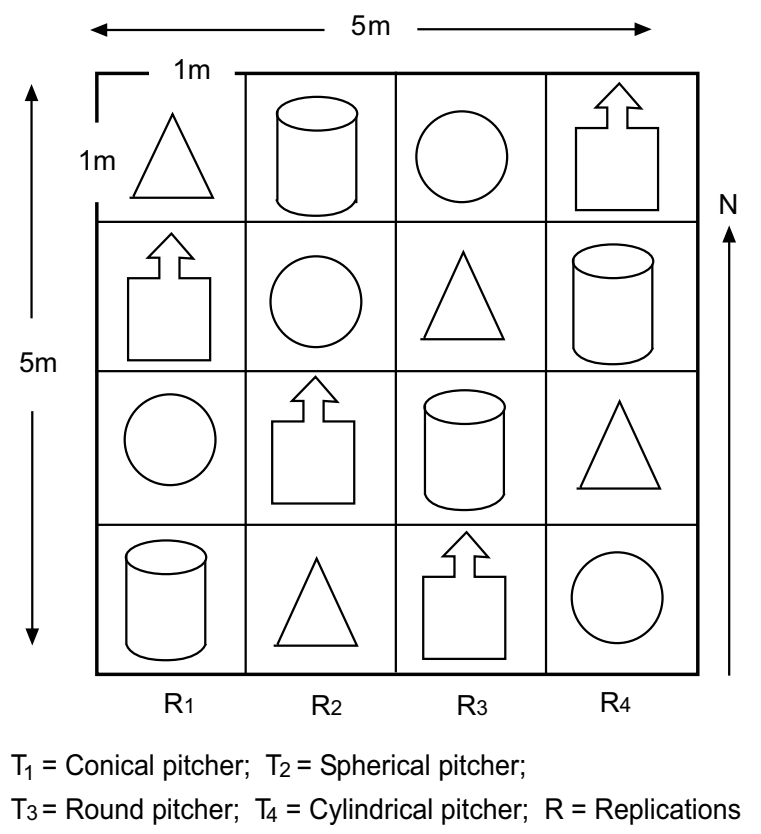

Fig. 2. The experimental field layout. 
wet samples weight ' $W$ '. The oven drying was done at $105^{\circ} \mathrm{C}$ for $24 \mathrm{~h}$ and dry weight of the samples $\left(\mathrm{W}_{\mathrm{d}}\right)$ was recorded. The moisture content of soil was calculated by the equation given by Reeb et al. (1999).

$$
\theta_{\mathrm{w}}=\frac{\mathrm{W}_{\mathrm{w}}-\mathrm{W}_{\mathrm{d}}}{\mathrm{W}_{\mathrm{d}}} \times 100
$$

where:

$$
\begin{aligned}
& \theta_{\mathrm{w}}=\text { soil moisture content (\%age), } \\
& \mathrm{W}_{\mathrm{w}}=\text { weight of wet soil sample }(\mathrm{g}), \\
& \mathrm{W}_{\mathrm{d}}=\text { weight of oven dried soil sample }(\mathrm{g}) .
\end{aligned}
$$

For soil texture the Bouyoucos hydrometer method was used, digital pH meter (model SP-34 sunteor) used for $\mathrm{pH}$ determination and digital EC meter (model HI-8333) was used for measurement and determination of electrical conductivity. The preliminary soil data has been taken from experimental site and shown in Table 1.

Installation of pitchers. For pitcher installation 16 circular pits of $60 \mathrm{~cm}$ depth and $90 \mathrm{~cm}$ diameter were dug to place pitchers in them. Four different shape pitchers i.e., conical $\left(T_{1}\right)$, spherical $\left(T_{2}\right)$, round $\left(T_{3}\right)$ and

Table 1. Soil characteristics of selected site

\begin{tabular}{ll}
\hline \hline Parameters & Soil data \\
\hline Soil texture & Silt loam \\
Dry bulk density $\left(\mathrm{gm} / \mathrm{cm}^{3}\right)$ & 1.47 \\
Infiltration rate $(\mathrm{cm} / \mathrm{hr})$ & 1.59 \\
Field capacity $(\%)$ & 27.5 \\
Available moisture $(\%)$ & 12.3 \\
\hline \hline
\end{tabular}

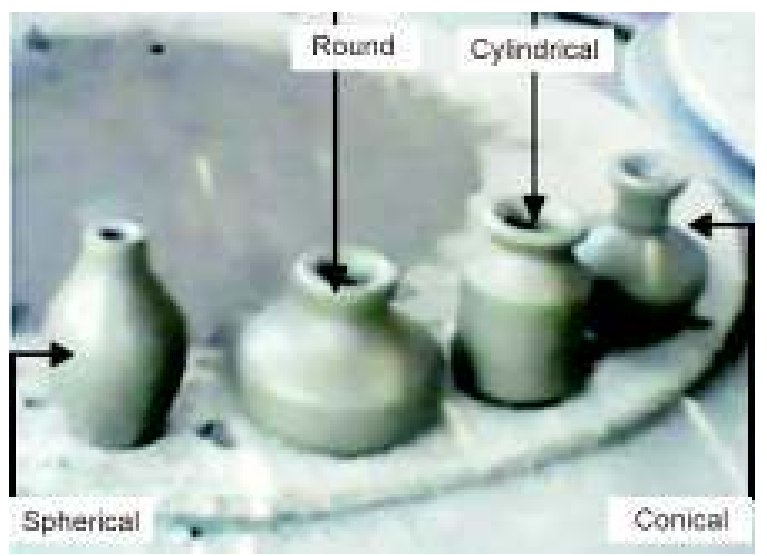

Fig. 3. Different shapes of Pitchers. cylindrical $\left(\mathrm{T}_{4}\right)$ having capacity of 1.7, 1.3, 1.3 and 1.08 $\mathrm{m}^{3}$ volume of water under $T_{1}, T_{2}, T_{3}$ and $T_{4}$, respectively were installed as shown in Fig. 3.

The farm yard manure was filled in each pit $30 \mathrm{~cm}$ depth, after which the pitchers were placed in centre of each pit, the left-over space in each pit was then filled with (farm yard manure and soil) from neck to bottom of each pitcher. The submerged pitchers were completely filled out with ground water through buckets up to their necks with a required volume and the lid was put back on. Ridge gourd crop was planted immediately a day after pitcher filling then subsequent irrigation was done.

Crop sowing and fertilizer application. Four to six seeds of ridge gourd were planted around the pitcher in each replication of moist soil during the month of April 2016. The favorable location of the seedbed was just above the farthest boundary of the pitcher wall. In the seed pot water up to $1 \mathrm{~cm}$ depth was added in order to keep soil moist and allow capillary action from the buried clay pitcher. About $5 \mathrm{~g}$ of the mixture of potassium, phosphorus and nitrogen was added to each pitcher, respectively at interval of one week as recommended by Mondal et al. (1987).

Water use efficiency and water saving. The mature ridge gourd crop was ready to harvest in June 2016 with one week interval up to July 2016 . The yield was harvested and weighed with electrical weighing machine based on per pitcher and per hectare basis by assuming 2500 pitchers per hectare. However, the water use efficiency of the pitcher irrigation method per pitcher was determined with the following relationship in equation:

$$
\mathrm{WUE}=\mathrm{Y}_{\mathrm{p}} / \mathrm{W}
$$

where:

$$
\begin{aligned}
& \text { WUE }=\text { water use efficiency }\left(\mathrm{kg} / \mathrm{m}^{3}\right) \\
& \mathrm{Y}_{\mathrm{p}}=\text { total crop yield }(\mathrm{kg} / \text { pitcher }) \\
& \mathrm{W}=\text { total water used }\left(\mathrm{m}^{3} / \mathrm{pitcher}\right)
\end{aligned}
$$

Water saving was calculated in comparison between depth of water used under pitcher irrigation and flood irrigation methods. The water depth of $500 \mathrm{~mm}$ was considered (MINFAL, 2005) and determined by the following equation:

$$
\mathrm{WS}(\%)=\frac{\mathrm{D}_{\mathrm{f}}-\mathrm{D}_{\mathrm{p}}}{\mathrm{D}_{\mathrm{f}}} \times 100
$$


where:

$\mathrm{WS}=$ water saving $(\%)$

$\mathrm{D}_{\mathrm{p}}=$ depth of water consumed with pitcher irrigation (mm).

$\mathrm{D}_{\mathrm{f}}=$ depth of water consumed with flood irrigation $(600 \mathrm{~mm})$.

\section{Results and Discussion}

The soil electrical conductivity (EC) wetted by different pitcher shapes were 2.03, 2.98 and $1.58 \mathrm{dS} / \mathrm{m}$ under $\mathrm{T}_{1}, 2.50,2.11,1.93 \mathrm{dS} / \mathrm{m}_{\text {under }} \mathrm{T}_{2}, 2.75,1.90,1.52$ $\mathrm{dS} / \mathrm{m}$ under $\mathrm{T}_{3}$ and $3.32,2.65,1.30 \mathrm{dS} / \mathrm{m}$ under $\mathrm{T}_{4}$ shape at $0-20,20-40,40-60 \mathrm{~cm}$ depths, respectively. The effect of $\mathrm{T}_{4}$ shape pitcher showed maximum soil EC $(3.32 \mathrm{dS} / \mathrm{m})$ at $0-20 \mathrm{~cm}$ depth whereas $\mathrm{T}_{4}$ pitcher showed minimum soil EC $(1.30 \mathrm{dS} / \mathrm{m})$ at $40-60 \mathrm{~cm}$ depths as shown in Fig. 4.

It is evident that $\mathrm{EC}$ was significantly higher at surface soil, which declined with an increase in soil depths at sub surface layer. The average pitcher EC of $\mathrm{T}_{4}$ shape had $5.45 \mathrm{dS} / \mathrm{m}$ followed by $\mathrm{T}_{3}(4.97 \mathrm{dS} / \mathrm{m}), \mathrm{T}_{2}(3.84$ $\mathrm{dS} / \mathrm{m})$ and $\mathrm{T}_{1}(3.63 \mathrm{dS} / \mathrm{m})$. At surface of soil the $E C$ of soil was higher and the EC dropped with an increase in the soil depth from subsurface layers. $T_{3}$ pitcher results showed lower soil EC followed by $\mathrm{T}_{2}$ and $\mathrm{T}_{3}$. However, the $\mathrm{T}_{4}$ pitcher resulted in highest soil $\mathrm{EC}$ as compared to rest of the pitchers having different shapes. The results are in line with Vasudevan et al. (2011), who reported that salts distribution in soil around the pitchers increases in horizontal distance from pitcher and decrease on moving vertically downwards.

The soil $\mathrm{pH}$ wetted by different shapes pitcher was 8.2 , 8.3 and 8.4 under $\mathrm{T}_{1}$ shape, 8.2, 8.2, 8.3 under $\mathrm{T}_{2}, 8.3$,

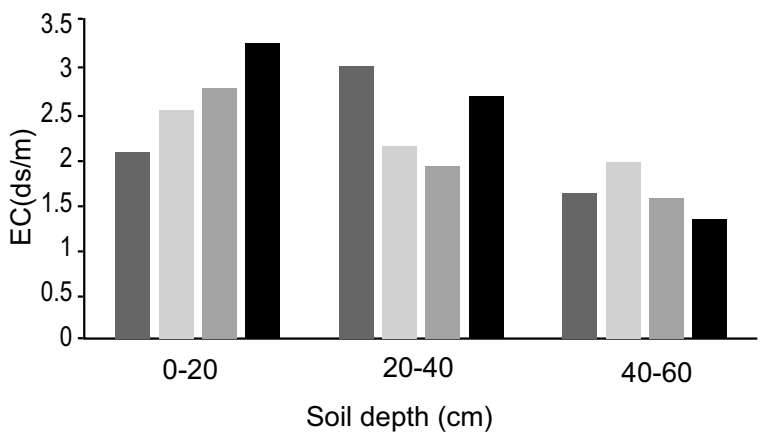

$\mathrm{T}_{1}-\mathrm{T}_{2} \square \mathrm{T}_{3} \quad \mathrm{~T}_{4}$

Fig. 4. $E C$ at different depths under $T_{1}, T_{2}, T_{3}$ and $\mathrm{T}_{4}$.
8.3, 8.2 under $\mathrm{T}_{3}$ and 8.2, 8.0, 8.2 under $\mathrm{T}_{4}$ at $0-20,20$ 40, 40-60 cm depths, respectively as shown in Fig. 5. The results showed that $T_{1}$ shape at $40-60 \mathrm{~cm}$ depth has maximum soil $\mathrm{pH}$ of 8.4 and $\mathrm{T}_{4}$ pitcher at $20-40 \mathrm{~cm}$ depths has minimum soil $\mathrm{pH}$ of 8.0. It is evident that $\mathrm{pH}$ at surface soil was substantially higher that declined with increasing soil depths at sub surface layer. These findings were supported up to some extent by Stein (1997), who reported that the surface area of pitcher and hydraulic conductivity along with other factors significantly affect the seepage rate from the pitchers.

While pitcher filled up to neck with water under natural atmospheric conditions observed that the pitcher shape and size have impact on the soil property (Vasudevan et al., 2014). Furthermore, the soil properties changes with the pitcher size and shape variation (Siyal et al., 2015).

Agronomic observations. The lengths of ridge gourd vines under $T_{1}, T_{2}, T_{3}$ and $T_{4}$ were measured, highest was found to be as $211 \mathrm{~cm}$ under $T_{4}$ pitcher followed by $T_{3}, T_{1}$ and $T_{2}$. However, the lowest length of vine was obtained under $T_{2}$ as $139 \mathrm{~cm}$ as shown in Fig. 6 . Although the vine length was greater under $T_{4}$ but the $\mathrm{T}_{3}$ pitcher consumed more water as compared to the other pitchers. However, no increase in quantity of ridge gourd fruit was observed. Perhaps, this remarkably greater growth performance under $T_{3}$ was linked to more water refilling in contrast to $\mathrm{T}_{1}, \mathrm{~T}_{2}$ and $\mathrm{T}_{4}$. The results are in line with vanKoppen et al. (2015) who reported that the cumulative root growth around pitchers increased the seepage rates initially and decreased ultimately with the increase in length of the roots of certain deep rooting crops.

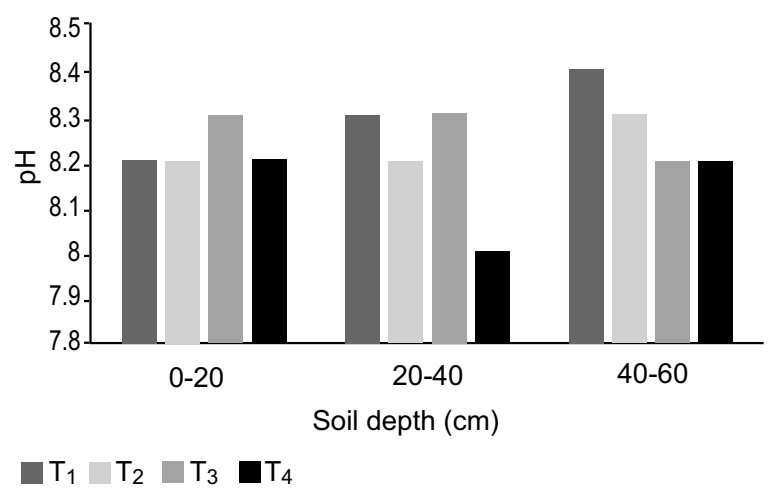

Fig. 5. $\mathrm{pH}$ at different depths under $\mathrm{T}_{1}, \mathrm{~T}_{2}, \mathrm{~T}_{3}$ and $\mathrm{T}_{4}$. 


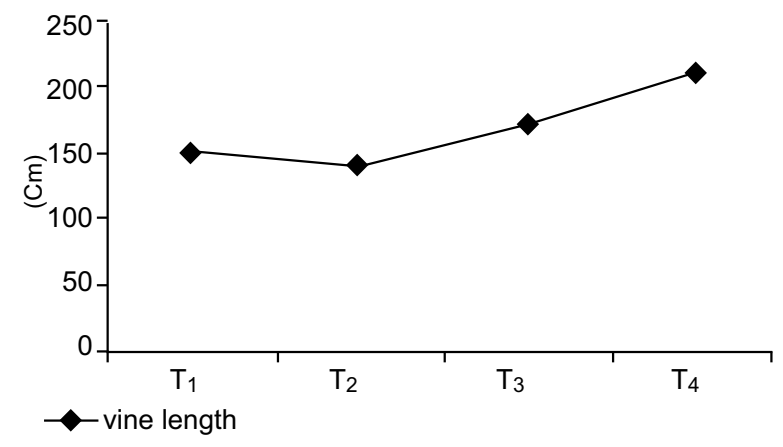

Fig. 6. Ridge gourd growth (Vine length) under $\mathrm{T}_{1}, \mathrm{~T}_{2}, \mathrm{~T}_{3}$ and $\mathrm{T}_{4}$.

Water use efficiency and water saving. The water use efficiency of ridge gourd was highest as $8.6 \mathrm{~kg} / \mathrm{m}^{3}$ under $T_{4}$ followed by $T_{2}, T_{1}$ and $T_{3}$. However, the lowest water use efficiency was obtained under $\mathrm{T}_{3}$ which was $6.2 \mathrm{~kg} / \mathrm{m}^{3}$ as shown in Fig. 7. The results indicate that traditional pitcher method can prevent huge amount of water losses, especially in arid and semi-arid regions. Furthermore, pitcher irrigation could save up to $60 \%$ and $30 \%$ of water compared to surface and drip irrigations, and it facilitates water absorption due to its continuous and auto-regulative seepage which was reported while doing experiment at Mashad, Iran (Ansari et al., 2015). In our study $\mathrm{T}_{4}$ proved to be the most economical in terms of water saving. Our results are in line with those of Malekinezhad (2015) results that the total fruit yield under pitcher irrigation was higher as $8.61 \mathrm{~kg} / \mathrm{plant}$ followed by $7.86 \mathrm{~kg} / \mathrm{plant}$ under furrow irrigation mode (Malekinezhad, 2015).

The water saving was highest as $82.0 \%$ under $\mathrm{T}_{4}$ followed by $T_{2}, T_{1}$ and $T_{3}$ while the lowest water saving was obtained as $75 \%$ under $T_{3}$ as shown in Fig. 8. However, $\mathrm{T}_{4}$ and $\mathrm{T}_{2}$ were more efficient to consume

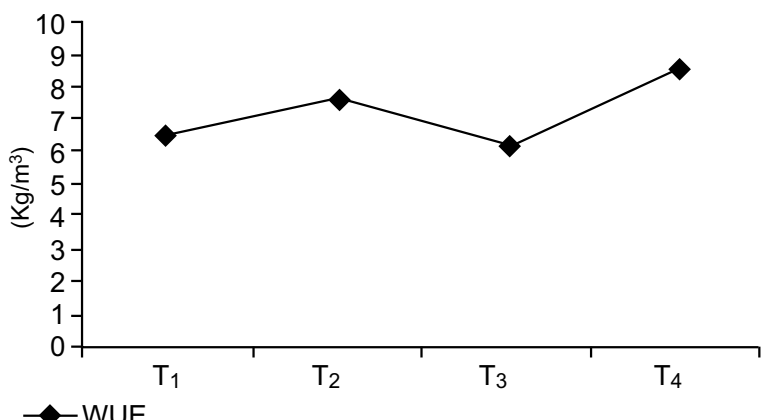

Fig. 7. Water use efficiency of ridge gourd under $\mathrm{T}_{1}, \mathrm{~T}_{2}, \mathrm{~T}_{3}$ and $\mathrm{T}_{4}$. minimum amount of water per hectare and this is in line with Pachpute (2010) who reported that the soil moisture in root zone was maintained in pitcher positively as per the crop water requirement, resulting in increased yield as well as higher water use efficiency.

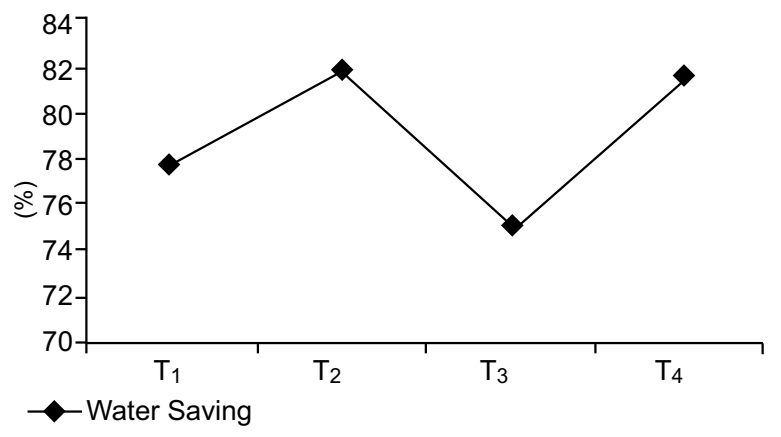

Fig. 8. Water saving (\%) of ridge gourd under $T_{1}$, $\mathrm{T}_{2}, \mathrm{~T}_{3}$ and $\mathrm{T}_{4}$.

\section{Conclusion}

At surface soil the EC of soil was substantially higher and the EC dropped with an increase in the soil depth at subsurface layers. The maximum soil EC $3.32 \mathrm{dS} / \mathrm{m}$ under $\mathrm{T}_{4}$ at $0-20 \mathrm{~cm}$ depth was found while the minimum $\mathrm{pH}$ as 8.0 was under $\mathrm{T}_{4}$ at $20-40 \mathrm{~cm}$ which was considerably higher at surface soil that declined with increasing soil depths at sub surface layer. The highest ridge gourd yield recorded under $T_{4}$ was $9485 \mathrm{~kg} / \mathrm{ha}$ with the highest water use efficiency as $8.6 \mathrm{~kg} / \mathrm{m}^{3}$. The highest vine length of ridge gourd was found as $211 \mathrm{~cm}$ under $\mathrm{T}_{4}$ pitcher and the lowest length of vine was obtained under $T_{2}$ as 139 $\mathrm{cm}$. The pitcher irrigation system is highly economical and regarded as most effective in production of ridge gourds. Hence, it is concluded that pitcher irrigation system is extremely efficient and cost-effective method to produce ridge gourds and can be made more useful tool for small-scale farmers while combined with water harvesting techniques such as rainwater catchment systems.

\section{References}

Abu-Zreig, M.M., Atoum, M.F. 2004. Hydraulic characteristics and seepage modelling of clay pitchers produced in Jordan. Canadian Biosystems Engineering, 46: 1.15-1.20.

Agarwal, A. 2000. Drought? Try Capturing the Rain. pp. 1-16, Center for Science and Environment, New Delhi, India.

Alemi, M.H. 1981. Distribution of water and salt in soil 
under trickle and pot irrigation regimes. Agricultural Water Management, 3: 195-203.

Ansari, H., Naghedifar, M.R., Faridhosseini, A. 2015. Performance evaluation of drip, surface and pitcher irrigation systems. A Case Study of Prevalent Urban Landscape Plant Species. International Journal of Farming and Allied Science, 4: 610-620.

Ayers, R.S., Westcost, D.W. 1985. Water Quality for Agriculture. FAO Irrigation \& Drainage Paper 29, Rev.1, Food and Agriculture Organization of the United Nations, Rome, Italy.

Bainbridge, D.A. 2001. Buried clay pot irrigation: a little known but very efficient traditional method of irrigation. Agricultural Water Management, 48: 79-88.

Bhatt, N., Kanzariya, B., Motiani, A., Pandit, B. 2013. An experimental investigation on pitcher irrigation technique on alkaline soil with saline irrigation water. International Journal of Engineering Science and Innovative Technology, 2: 206-212.

Bruinsma, J. 2003. World Agriculture: Towards 2015/ 2030: An FAO perspective: Earthscan, Publications Ltd., London, UK.

Gul, B., Khan, M.A. 2003. Saline Agriculture: Promises and prospects for future agriculture in degraded saline lands. In: Technology \& Development in the New Millennium, pp. 149-156, University of Karachi, Pakistan.

Hillel, D. 1997. Small-scale Irrigation for Arid Zones: Principles and Options: vol. 2, 56 pp., FAO Development Series, FAO, Rome, Italy.

Isbell, R.F. 1996. The Australian Soil Classification, CSIRO Publishing: Collingwood, Vic., Australia.

Ishfaq, M. 2002. Water New Technology. Global Water Institute, Lahore, Pakistan.

Kahlown, M., Majeed, A. 2003. Water-resources situation in Pakistan: Challenges and future strategies. In: Water Resources in the South: Present Scenario and Future Prospects, pp. 21-40, COMSATS' series, Islamabad, Pakistan.

Malekinezhad, H. 2015. Comparison of cucumber and watermelon yield and water use in clay pitcher and furrow irrigation methods. International Journal of Water, 9: 275-285.

MINFAL, 2005. Irrigation Agronomy Field Manual. Federal Water Management Cell, Ministry of Food, Agriculture and Livestock, Government of Pakistan, Islamabad, $81 \mathrm{pp}$.

Mondal, R., Dubey, S., Gupta, S. 1992. Use pitchers when water for irrigation is saline. Indian Agriculture, 36: 13-14.
Mondal, R., Gupta, S., Dubey, S., Bathwal, H. 1987. Pitcher irrigation: Central Soil Salinity Research Institute.

Pachpute, J.S. 2010. A package of water management practices for sustainable growth and improved production of vegetable crop in labour and water scarce Sub-Saharan Africa. Agricultural Water Management, 97: 1251-1258.

Qureshi, A.S. 2011. Water management in the Indus basin in Pakistan: Challenges and opportunities. Mountain Research and Development, 31: 252-260.

Reeb, J.E., Milota, M.R. 1999. Moisture content by the oven-dry method for industrial testing, Western Dry Kiln Association 50 $0^{\text {th }}$ Meeting, Oregon State University Corvallis, USA.

Sheng, H.S. 1974. Fan Sheng-Chih Shu: An Agriculturist Book of China, Written by Fan Sheng-Chih in the First Century BC: Science Books, Beijing, China.

Siyal, A.A., Siyal, A.G., Siyal, P., Solangi, M., Khatri, I. 2016. Pitcher irrigation: Effect of pitcher wall properties on the size of soil wetting front. Science International (Lahore), 28: 1299-1304.

Siyal, A.A., Soomro, S.A., Siyal, A.G. 2015. Performance of Pitcher Irrigation with saline water under high evapotranspiration rates. Journal of Chinese Soil and Water Conservation, 46: 61-69.

Siyal, A.A., Van Genuchten, M.T., Skaggs, T.H. 2013. Solute transport in a loamy soil under subsurface porous clay pipe irrigation. Agricultural Water Management, 121: 73-80.

Stein, T.M. 1997. The influence of evaporation, hydraulic conductivity, wall thickness and surface area on the seepage rates of pitchers for pitcher irrigation. Journal of Applied Irrigation Science, 321: 65-83.

Tesfaye, T., Tesfaye, K., Woldetsadik, K. 2011. Clay pot irrigation for tomato (Lycopersicon esculentum Mill) production in the north east semiarid region of Ethiopia. Journal of Agriculture and Rural Development in the Tropics and Subtropics, 112: 11-18.

vanKoppen, B., Lacombe, G., Mwendera, E. 2015. Trends and Outlook: Agricultural Water Management in Southern Africa. Synthesis Report. USAID Project Report, Colombo, Sri Lanka.

Vasudevan, P., Thapliyal, A., Tandon, M., Dastidar, M., Sen, P. 2014. Factors controlling water delivery by pitcher irrigation. Irrigation and Drainage, 63: 71-79.

Vasudevan, P., Bhumija, K., Srivastava, R. 2011. Buried clay pot irrigation using saline water. Journal of Scientific and Industrial Research, 70: 653-655. 